\title{
CZY ISTNIENIE MOŻE BYĆ LEPSZE ALBO GORSZE OD NIEISTNIENIA? \\ CZĘŚĆ I: USTALANIE WARTOŚCI W RAMACH DOBROSTANU
}

Słowa kluczowe: istnienie, nieistnienie, dobrostan, wartość osobowa Keywords: existence, nonexistence, wellbeing, person's value

Każdy z nas mógłby nie istnieć. Zrozumienie takiej możliwości w naturalny sposób rodzi pytanie, co jest dla nas lepsze: czy to, że zostaliśmy powołani do istnienia, czy też to, że gdyby tak się nie zdarzyło, nigdy byśmy nie istnieli. $\mathrm{Ci}$, którzy własnym zachowaniem w świadomy sposób przyczyniają się do zaistnienia ludzi, podejmując w tej sprawie ostateczne i przemyślane decyzje, muszą borykać się z podobnym problemem, gdy postanawiają upewnić się, jaką wartość z punktu widzenia osoby powoływanej przez nich do istnienia będzie miało jej życie.

W tej sprawie nie ma jednomyślności. Jedni za całkowicie niedorzeczne uważają tak postawione pytania oraz problem, jaki mają one rzekomo wywoływać. Drudzy zaś nie negują możliwości udzielenia poprawnej odpowiedzi

* Mirosław Rutkowski - profesor US, kierownik Zakładu Etyki w Instytucie Filozofii Uniwersytetu Szczecińskiego.

Address for correspondence: Mirosław Rutkowski, Institute of Philosophy, University of Szczecin, ul. Krakowska 71, 71-017 Szczecin. E-mail: rutkowski1957@gmail. com. 
lub rozwiązania tej kwestii w ramach żadnej z przedstawionych perspektyw. Tutaj zdania są jednak również podzielone. Niektórzy bronią stanowiska, że odpowiedź możliwa jest w obu przypadkach i że jest zasadniczo taka sama w każdym z nich. Inni natomiast dochodzą do wniosku, że choć można jej udzielić zarówno w jednej, jak i w drugiej sytuacji, to jednak w każdej $\mathrm{z}$ nich brzmi ona inaczej, punkt widzenia bowiem, z jakiego próbuje się ją formułować, decydująco wpływa na jej treść.

Pogląd, który głosi, iż w moralnej perspektywie można ustalić ostateczną hierarchię pomiędzy istnieniem i nieistnieniem, uważam za bezsprzecznie błędny. Sądzę, że jeśli odnosimy się do stanu, w którym istnienie jeszcze nie nastąpiło, niczego godnego uwagi nie potrafimy orzec o wartości nieistnienia, choć na ogół zgadzam się z tymi, którzy twierdzą, że po zaistnieniu możemy decydować, czy chcemy, czy też nie chcemy przeżywać dalej swoje życie (Parfit, 2012, s. 557). Oznacza to, iż zasadniczo podzielam opinię, że nie sposób powiedzieć czegokolwiek sensownego o aksjologicznej ekwiwalentności własnego zaistnienia i niezaistnienia. Uważam ponadto, że wypowiedzi udzielane przez osoby trzecie na temat wartości, jaką dla jakiejś istoty ludzkiej ma jej życie - z powodu niemożności posiadania potrzebnej do tego celu wiedzy i braku odpowiednich kompetencji - stanowią w wielu przypadkach nieuzasadnione nadużycie prawa do wypowiadania się w imieniu innych ludzi. Każdy, kto ma na ten temat podobne zdanie, musi zatem zakładać, iż wysiłki podejmowane w celu dokonania porównawczej oceny istnienia i nieistnienia, są w istocie rzeczy trudem całkowicie daremnym.

Na początek chciałbym odnieść się do niektórych problemów leżących $\mathrm{u}$ podstaw trudności, jakie rodzi postawione w tytule pytanie, i pokazać wszystkie zawiłości oraz całą złożoność przedmiotu, którego ono dotyczy. Moja analiza będzie jednak ogólna i niekompletna, gdyż wyczerpujące i systematyczne omówienie zagadnień, które należałoby poruszyć, aby udzielić prawidłowej odpowiedzi, przekracza ramy tego artykułu. Skupię się po prostu na rozróżnieniu pomiędzy wartościami osobowymi a moralnymi oraz spróbuję sformułować kilka sensownych uwag o kłopotach, z jakimi borykają się obrońcy obiektywności w etyce, gdy zakładają, że kwestie pojawiające się w ramach czyjegoś dobrostanu można rozwiązywać z zewnętrznego punktu widzenia. To spowoduje, że będę również zmuszony do powiedzenia czegoś na temat właściwego rozumienia samego pojęcia dobrostanu.

Wydaje się, iż przynajmniej jedna sprawa nie powinna budzić zastrzeżeń, a mianowicie, że najbardziej ogólne i powszechne rozumienie 
pomyślności, szczęścia bądź jakości życia zawsze odnosi się do tego, co sprawia, że istnienie pewnej osoby jest dobre lub złe dla niej samej, a to oznacza, że każda tego rodzaju próba wyznaczenia wartości życia polega na ocenianiu w ramach dobrostanu konkretnej osoby. W tak zdefiniowanym przedsięwzięciu nie poszukuje się więc odpowiedzi na pytanie, jaką wartość ma życie samo w sobie; chodzi raczej o to, aby dowiedzieć się, jaka wartość ma ono dla tej osoby. Oczywiście, naszemu życiu można przypisać również wartość bezosobową. Dzieje się tak na przykład wówczas, gdy rozpatrujemy je, jak to czynił choćby Kant, z punktu widzenia założeń eliminujących całkowicie odrębność osób lub w ramach złożonego mechanizmu kalkulacji o charakterze utylitarystycznym, gdzie nie występuje już ono jako życie tej lub innej osoby, ale jako czysto abstrakcyjny i pozaosobowy stan rzeczy, który posiada określoną wartość nie dlatego, że jest tożsama z jakimś podmiotem, lecz głównie z tego powodu, że może wpłynąć na ostateczną i całkowitą ilość dobra i zła, jaka istnieje w świecie. Podobny skutek zostaje osiągnięty również wtedy, gdy założy się, że każde życie cechuje się jakąś wartością autoteliczną. Moore, który był jednym z najbardziej żarliwych protagonistów tego rodzaju idei i wykonał olbrzymi wysiłek, abyśmy prawidłowo rozumieli istotę tak pojmowanego piękna, dobra oraz zła moralnego, zakładał, iż powiedzenie, że jakiś rodzaj wartości jest wewnętrzny, oznacza, że odpowiedź na pytanie, czy pewna rzecz ją posiada, zależy tylko od natury tej rzeczy, pojmowanej jako byt sam w sobie, i w żadnej mierze nie wynika z własności przysługujących jakiemukolwiek podmiotowi (Moore, 2003, s. 130-135). Ten neutralny punkt widzenia, choć możliwy jest do zastosowania, nie ma jednak, jak się wydaje, większego znaczenia dla kwestii egzystencjalnych o charakterze osobistym. Kiedy interesuje nas wzajemna ocena naszego własnego istnienia i nieistnienia, a nawet gdy pytamy o tego typu ocenę w odniesieniu do konkretnej istoty ludzkiej, stanowiącej odrębny i autonomiczny podmiot, to zwykle nie chodzi nam o porównywanie rzeczy, które są w ten sposób dobre lub złe same w sobie, lecz o to, jaką mają one wartość dla nas lub dla jakiejś innej osoby. Jeśli ktoś mówi, iż wolałby się nie urodzić lub, że byłoby lepiej, gdyby się nie urodził, to zakładając, że wypowiada się w ten sposób po starannym namyśle, a nie pod wpływem jakichś nagłych i niespodziewanych wydarzeń, które doprowadziły go do zaburzeń zdrowego rozsądku lub do emocjonalnej zapaści, większość z nas zrozumie tę wypowiedź tak, że osoba ta najprawdopodobniej doszła do wniosku, iż dla niej samej byłoby lepiej, gdyby się nie urodziła, a nie, 
że byłoby to $w$ ogóle lepsze dlatego, gdyż jej nieistnienie z obiektywnego i bezosobowego punktu widzenia miałoby większą wartość wewnętrzną niż jej istnienie lub, że w takim stanie rzeczy dużo korzystniejsze byłoby ostateczne saldo ujemnych oraz dodatnich wartości w świecie.

Nie wszyscy podzielają taką opinię. Niektórzy zwolennicy obiektywnych i bezstronnych wartości stoją na stanowisku, iż nie muszą z tego powodu zaprzeczać, jakoby osoba, która zastanawia się nad porównawczą oceną własnego istnienia i nieistnienia, była niezdolna do jej sformułowania na podstawie sądu dotyczącego tego, co jest lepsze lub gorsze dla niej samej. Zakładają oni, że głosząc ten pogląd, nie robią niczego, co przeczyłoby twierdzeniu, że indywidualne opinie dotyczące wartości własnego życia są $\mathrm{w}$ istocie rzeczy niezależne od własności, jakimi cechuje się ta osoba. Warto zwrócić uwagę, że odseparowanie subiektywnych przekonań od bezosobowego charakteru wspomnianych sądów egzystencjalnych występuje w tym stanowisku nawet wtedy, gdy neutralną wobec podmiotu perspektywę objaśnia się w kategoriach tego, co ma taką lub inną wartość z jednostkowego punktu widzenia. Jest tak dlatego, gdyż przyjmuje się, iż to, co ktoś uważa za dobre dla siebie, może być takie wyłącznie z tego powodu, że jest jednocześnie dobre samo w sobie lub że taką bezwzględną wartość ma jego posiadanie. Na skutek takich założeń łatwo dojść do wniosku, że jeśli czasami zdarza się nam wypowiadać sądy o tym, co uważamy za dobre lub złe dla nas samych, to powinniśmy mieć świadomość, iż w roli tej nigdy nie występujemy jako realne podmioty, lecz zawsze jako osoby całkowicie abstrakcyjne, których oceny na temat wartości ich własnego istnienia bądź nieistnienia mogą stanowić właściwy wzorzec aksjologicznych decyzji tylko wtedy, gdy abstrahując od tego, kim faktycznie jesteśmy, potrafimy jednocześnie odkryć wewnętrzną wartość rzeczy.

W ten sposób powiedzenie, że coś jest dla mnie dobre, staje się podobne pod pewnym względem do powiedzenia, że coś jest dla mnie prawdziwe. O ile uznamy za słuszne, że jeśli jakaś osoba błędnie twierdzi, że p, to nie sposób zakładać, że p jest ,prawdziwe dla tej osoby”, wówczas uzasadnione wydaje się również przypuszczenie, iż nie można by twierdzić, że „coś jest dobre dla kogoś", gdyby okazało się, że nie jest ono dobre samo w sobie. Słuszność tego, co mam do powiedzenia o tym, co może być dobre lub złe dla mnie, w konkretnych okolicznościach zależałaby zawsze od udzielenia prawidłowej odpowiedzi na pytanie, czy jakaś rzecz jest dobra lub zła w sposób bezwzględny. Jeżeli na temat wartości tej rzeczy mam prawid- 
łowe domniemanie, tzn., gdy sądzę, że jest ona dobra bezwzględnie, i tak faktycznie mają się sprawy, to prawdą jest, że i dla mnie jest ona dobra. Jeżeli natomiast moje przypuszczenia w tej kwestii są błędne, tzn., gdy sądzę, że jest ona w taki sposób dobra, lecz w rzeczywistości jest inaczej, to w żadnym razie nie może być prawdą, jakoby ta rzecz była dobra dla mnie (Moore, s. 158; Hurka, 1987, s. 71-72; Rosati, 2008, s. 314-315; Smith, 2003, s. 576-598; Sumner, 2003, s. 47-53).

Uznanie tak rozumianego bezosobowego charakteru ocen oraz niektórych konsekwencji, do jakich prowadzi taka decyzja, powoduje, że powiedzenie, iż coś jest dobre dla jakiejś osoby, uważane może być za czynność generującą w nieuchronny sposób sądy wewnętrznie sprzeczne. W przyjętym modelu wyrażenie ,dobry dla” zakłada bowiem pojęcie dobra definiowanego niezależnie od wszelkich własności cechujących osobę - a tym samym umożliwia jeszcze bardziej ogólne założenie, że jest ono niezależne również od istnienia jakichkolwiek osób - jednakże użyty przyimek dla, który w taki sposób precyzuje zakres odniesienia tego pojęcia, że ostatecznie uzależnia w jakimś stopniu jego treść od osoby będącej przedmiotem tej relacji, wyklucza $\mathrm{w}$ istocie rzeczy tak rozumianą ideę dobra, gdyż przeczy przyjętemu założeniu o jej całkowitej neutralności wobec podmiotu (Regan, 2004, s. 211-213). Autoteliczny status wartości, jaki zakłada ta koncepcja, wyklucza nie tylko możliwość decydowania o tym, co jest dobre dla mnie na podstawie tego, czego sam doświadczam i doznaję, lub na podstawie moich własnych decyzji w tym zakresie, ale sięga o wiele głębiej i zakłada, że nie mogę niczego sensownego na ten temat powiedzieć nawet wówczas, gdy będę posiadał pełną zdolność do abstrahowania w swoich sądach aksjologicznych od własnej osobowości i związków ze światem i gdy moje oceny nie będą z tego powodu miały charakteru jednostkowego, lecz będą jedynie uosabiać wybory innych ludzi, którzy dokonaliby ich, będąc na moim miejscu. W tej perspektywie rezygnacja $\mathrm{z}$ indywidualności i niepowtarzalności nie stanowi wystarczającego kryterium słuszności wygłaszanych sądów na temat tego, co jest dobre dla nas samych; wymagane jest spełnienie dużo bardziej drastycznego warunku - eliminacji samego podmiotu, rozumianego jako pierwotne i konieczne źródło istnienia tego typu wartości. Mówiąc, że coś jest dobre dla mnie, nie mogę jednak uczynić zadość temu żądaniu. Jeśli wypowiedź ta zakłada, że wobec braku mojego istnienia nic nie mogłoby być dla mnie dobre w takim znaczeniu, jakie gwarantuje moje istnienie, oznacza to, iż wartość, o której mowa, nie jest w pełni neutralna i bezwarunkowa. 
Nie zamierzam wdawać się w dyskusję, czy słuszna jest teza, że wartości bezosobowe są w istocie rzeczy jedynym rodzajem dobra i zła, jakim możemy dysponować w ramach naszego dobrostanu; nie zamierzam nawet rozstrzygać kwestii, czy są to wartości najważniejsze. Jeśli uwagi zawarte na ten temat w pracach Moore'a oraz Regana nie są pozbawione znaczenia - a o tym jestem przekonany - to należałoby uważać, iż generowane przez nie oceny opisują pewną ważną społecznie formę zainteresowania, jaką każdy z nas powinien okazywać innym ludziom w ramach troski o własne dobro. Choć nie wykluczam istnienia wartości, które są w ten sposób neutralne, chciałbym powiedzieć również coś o tym, w jaki sposób nasze poglądy na temat tego, co jest dobre, determinowane są przez własności, które charakteryzują nas samych. Ten punkt widzenia zwykło się opisywać w kategoriach wartości względnych wobec podmiotu. Jego zwolennicy zakładają na ogół, że coś może być dobre lub złe tylko wtedy, gdy będziemy mogli powiedzieć, iż jest dobre lub złe dla jakiejś osoby z powodu doznań, jakich ona doświadcza, lub ze względu na dające się jej przypisać cechy - jak choćby posiadanie określonych interesów, zdolności, czy zasobów materialnych - które nie muszą objawiać się w ramach przysługujących jej w tym czasie stanów mentalnych (Glover, 1977, s. 66-69; Nagel, 1997, s. 201-229). Wbrew temu, co myślą niektórzy, to nie jest przyzwolenie na subiektywny punkt widzenia. Definiowanie wartości ze względu na własności przysługujące poszczególnym osobom nie oznacza, że całkowicie poniechana została zasada bezstronności i że każdy może formułować oceny na temat dobra i zła $\mathrm{z}$ własnego, jednostkowego, punktu widzenia. Stanowisko to zakłada dość mocny wymóg uniwersalizowalności, zgodnie z którym konkretne okoliczności, w jakich znajduje się podmiot, a także jego specyficzne doznania i cechy stanowić mogą źródło wartości tylko wtedy, gdy traktowane są jako ogólne własności przypadające każdej tego typu sytuacji i każdej znajdującej się w niej osobie. Warto też pamiętać, że wszystkie najważniejsze koncepcje dobrostanu, obejmujące hedonistyczną teorię stanów mentalnych, teorię preferencji, czy też teorię listy obiektywnej (Parfit, 2012, s. 20, 563-572; Sumner, 2003, s. 45-80, 81-112, 113-137; Saja, 2015, s. 80-83), posiadają katalog wybranych rzeczy (składający się między innymi z takich własności, jak: doznawanie przyjemności oraz przykrości, zaspokojenie pragnień, rozwój zdolności, świadomość dobra lub piękna, pozbawienie wolności, racjonalne myślenie i działanie, bycie ofiarą oszustwa, zdrady czy lekceważenia itd.), które w sposób arbitralny 
uznawane są za dobre albo za złe dla jakiejś osoby bez względu na to, jaką wartość miałyby one dla niej z jej własnego punktu widzenia.

Tego rodzaju wartości względne wobec podmiotu nazywać będę relacjonalnymi. Pomimo iż swoje istnienie zawdzięczają głównie temu, że egzystują jacyś ludzie posiadający cechy, które są nośnikami tych wartości, jednak rzeczą nie do końca właściwą byłoby mówienie w takim przypadku, że mają one charakter subiektywny, a więc, że to, iż są takimi bądź innymi wartościami, wynika z faktu, że ci ludzie tak sądzą. Choć w sposób zasadniczy różnią się od wartości bezosobowych, które mogą funkcjonować niezależnie od egzystencji istot obdarzonych tego typu własnościami, przypominają je pod tym względem, że mają podobny wymiar obiektywności - ani ich istnienie, ani też ich natura nie są konstytuowane przez przekonania, jakie utrzymują na ten temat osoby będące ich podmiotami (Railton, 1986, s. 183). Gdy więc mówimy, że coś jest w ten sposób dobre lub złe dla jakiejś osoby, oznacza to, iż w jej życiu zaszły pewne zdarzenia lub cechują ją własności, których wartość uzasadnia taką właśnie, a nie inną ocenę, nie zakłada to jednak w żadnym razie, że te zdarzenia lub własności mają wskazaną wartość z tego powodu, że ta osoba tak właśnie czuje lub myśli. Własna pomyślność rozpatrywana w kategoriach wartości relacjonalnych pozwala na daleko idące ubezwłasnowolnienie podmiotu, i z tego powodu nie będzie zapewne przedmiotem pożądania przez tych, którzy chcieliby prowadzić w pełni zintegrowane życie, tj. postępować, opierając się na tym, co sami będą uważali za dobre lub złe dla siebie (Dworkin, 1993, s. 224; Brudney, 2009, s. 32). Jeśli pojęcie dobrostanu odnosimy do tego, co powoduje, że życie każdego z nas może być dobre lub złe dla niego samego, to kwestia, kto ustala, czym jest to coś, może decydować nie tylko o tym, jak duży jest w tym względzie zakres naszej autonomii w odniesieniu do możliwości definiowania jakości prowadzonego przez nas życia, ale również o tym, czy możemy podejmować w tym zakresie jakiekolwiek wiarygodne decyzje.

Aby odpowiedzieć na pytanie, czy w ramach dobrostanu możemy mieć do czynienia z tak rozumianymi wartościami relacjonalnymi, odwołam się do przykładu ekscentrycznego pacjenta:

Pewien człowiek, który nie ma rodziny ani przyjaciół, cierpi od kilkunastu lat na ciężką odmianę cukrzycy, w wyniku czego w jeden z palców u jego nogi wdała się gangrena. Stanowczo odmawiał leczenia, więc sprawy zaszły tak daleko, że z medycznego punktu widzenia palec trzeba teraz jak najszybciej amputować. Lekarze są zdania, że zwlekanie 
z operacją spowoduje niechybnie jego śmierć. Człowiek ten nie zgadza się jednak na zabieg, uzasadniając to swoim własnym dobrem. Na wniosek lekarza rodzinnego został on zbadany w miejscowym szpitalu psychiatrycznym, gdzie stwierdzono ponad wszelką wątpliwość, że nie jest chory umysłowo i ma takie same kompetencje do podejmowania decyzji na temat swego stanu zdrowia, jak każda inna normalna i dorosła osoba (Groll, 2011, s. 27-36) ${ }^{1}$.

Myślę, że większość z tych, którzy osobiście zetknęliby się z takim przypadkiem, doszłaby do wniosku, że dla pacjenta byłoby lepiej, gdyby mu amputowano palec. Nie mam też wątpliwości, że podczas rutynowej rozmowy mającej ustalić, jakie czynności medyczne należałoby w tej sytuacji podjąć, sami lekarze broniliby zawzięcie takiego właśnie stanowiska, a gdyby pomimo to pacjent miał odmienne w tej sprawie zdanie, niektórzy z nich być może nie byliby w stanie powstrzymać się przed zastosowaniem wyszukanej perswazji, aby po prostu narzucić mu swój własny punkt widzenia. To, że ludzie tak czynią, jest rzeczą dość zrozumiałą i w jakimś stopniu również naturalną. Wielu z nas jest przekonanych, że decyzja odnośnie do tego, jaki przebieg ma mieć nasze leczenie, jest kwestią wyłącznie wiedzy medycznej, a to prowadzi często do wniosku, że lekarz wie lepiej, co jest dla pacjenta dobre, a co złe. Uważamy również, że sądy wartościujące, które orzekają o tym, co jest dla pewnych osób dobre, a co złe, są w istocie rzeczy całkowicie homogeniczne. To oznacza, iż skłaniamy się ku temu, aby sądzić, że jeśli jakaś osoba stwierdziłaby, że zdarzenie, które się jej przydarzyło, ma dla niej taką, a nie inną wartość, to należałoby z tego wnosić, że w innym czasie i odmiennych okolicznościach miałoby ono taką samą wartość nie tylko dla tej osoby, ale również dla wszystkich pozostałych. Taką zasadę z powodzeniem stosujemy, wychowując własne dzieci. Odwołujemy się do niej również w procesie wychowawczym o charakterze publicznym, który przebiega w ramach instytucji szkolnych i oświatowych, a także bez oporów powołujemy się na nią w tych dziedzinach polityki społecznej, w których dokonuje się podziału ważnych dóbr. Stoimy bowiem na stanowisku, że żaden społecznie istotny rozdział korzyści i strat, czy też sprawiedliwe reguły stosowania kar oraz nagród, nie mogą opierać się na ocenach, któ-

\footnotetext{
1 W dalszej części wykorzystuję również artykuł D. Grolla Medicine and Well-Being, który ma się wkrótce ukazać w antologii The Routledge Handbook on Well-Being pod red. G. Fletchera.
} 
rych źródłem jest wyłącznie jednostkowy punkt widzenia uczestniczących w tym procesie osób. To zaś zakłada, że czasami musimy wyrazić zgodę, aby istniał powszechny obowiązek działania ze względu na powszechnie uznaną wartość, jaką stanowią one dla jakiejś osoby, nawet gdy ocena ta nie pochodzi bezpośrednio od podmiotu, którego dobro stanowi jedyną rację za tym, że mają być wykonane.

Przekonania te utracą swoją wiarygodność, gdy spróbujemy zastosować je do osób, które same mogą wnieść decydujący wkład w ustalenie, co jest dla nich dobrem. Takim właśnie przypadkiem zdaje się ekscentryczny pacjent. Ponieważ potrafi on samodzielnie określić, co jest, a co nie jest dla niego dobre z jego własnego punktu widzenia, to jeśli decyzja, jaką podjął na ten temat, spełnia pewne warunki, tzn. jest w pełni przemyślana i nie pociąga za sobą działania, którego skutki miałyby teraz lub w przyszłości jakiś bezpośredni oraz negatywny wpływ na innych ludzi bądź na zwierzęta, musimy uznać, że miał on prawo tak postąpić i że jego wybór jest ostateczny także dla osób trzecich. Jak słusznie zauważył Mill, na tym między innymi polega powszechnie aprobowana wolność i autonomia człowieka. Jeśli cenimy tego rodzaju przymioty naszego istnienia i jeśli zachodzą wymienione okoliczności, to w stosunku do normalnych dorosłych istot ludzkich nie można bez poważnych zastrzeżeń stosować paternalistycznej tezy, że wiemy lepiej niż oni sami, co jest dla nich dobre, a co złe. Z tego samego powodu nie wolno też zakładać, że moglibyśmy podjąć działanie na rzecz jakiejś osoby na podstawie posiadanego przekonania o tym, co jest dla niej dobre, jeśli przekonanie to nie byłoby podzielane przez osobę, dla dobra której mielibyśmy w ten sposób postępować (Brock, 1988, s. 550-565). Związek między wiedzą medyczną a dobrostanem pacjenta jest stosunkowo prosty i łatwy do zrozumienia. Idziemy do lekarza nie po to, żeby spowodować, aby nasze życie było dla nas jeszcze gorsze, lecz po to, aby z naszego własnego punktu widzenia stało się ono lepsze od tego, jakim było dotychczas. $Z$ drugiej strony, najważniejszym celem medycyny - który to cel powinien przyświecać również każdemu członkowi personelu medycznego - jest przyczynianie się do podnoszenia jakości życia pacjentów i sprzyjanie tym samym ich dobrostanowi. Z połączenia tych oczywistych prawd wynika jasno, że lekarz winien wykorzystywać najlepiej, jak potrafi swoje zawodowe umiejętności, aby realizować to, co jest dobre dla pacjenta. To jednak, co faktycznie jest dla niego dobre, nie stanowi w żadnym razie przedmiotu wiedzy, której pacjent miałby mniej tylko dlatego, że nie jest le- 
karzem. Wykształcenie nie daje nikomu żadnych szczególnych kwalifikacji, które mogłoby być pomocne w zdobyciu wiarygodnych informacji o tym, co jest dobre dla innego człowieka. Przekonanie, że dla jakiejś osoby byłoby lepiej żyć bez palca, niż umrzeć, nie stanowi zatem prawdy mieszczącej się w obszarze obiektywnej wiedzy, do której może odwołać się lekarz; jest ono raczej częścią tej wiedzy o nas samych, którą zdobywa się niejako od wewnątrz, tj. na drodze introspekcji, i która dotyczy tego, co jest dla nas dobre lub lepsze z naszego własnego punktu widzenia, a dostęp do niej może mieć wyłącznie podmiot, o którym mowa w tego typu przekonaniu. Oznacza to, iż zasadniczy dla praktyki medycznej aspekt analizowanego przypadku polega na tym, że lekarze nie są zdolni pomagać efektywnie w osiągnięciu wyższej jakości życia, gdy podejmują czynności medyczne wedle własnego osądu o tym, co jest dla ludzi dobre lub złe, mogą to natomiast zrobić wówczas, gdy postępować będą zgodnie $\mathrm{z}$ tym, co na ten temat mają do powiedzenia ich pacjenci (Veatch, 2009, s. 62).

Relacjonalna natura wartości zakłada, jak już tłumaczyłem, obiektywistyczną koncepcję tego, co jest dla kogoś dobre lub złe, która obejmuje między innymi twierdzenie, że ocenę taką można sformułować, nie wiedząc nawet, co miałaby do powiedzenia na ten temat osoba będąca jej przedmiotem. Gdyby był to jedyny rodzaj wartości względnych wobec podmiotu, to odwoływanie się do opinii tej osoby w celu ustalenia, co jest dla niej dobre, nie miałoby oczywiście większego sensu. Niezgodność własnych przekonań z prawidłowo uzasadnionym sądem na temat tego, co jest dla nas dobre, może być interpretowana bądź jako przygodny brak zdolności do rozpoznawania własnego dobra, bądź też, w wersji bardziej radykalnej, jako trwała niemożność zdefiniowania swojego dobrostanu. Obiektywna wiedza ma zawsze pierwszeństwo przed subiektywnym domniemaniem, a to pozwala nawet na całkowite ignorowanie jednostkowych przekonań w przypadku wystąpienia tego rodzaju rozbieżności. Rzecz jednak w tym, że wartości relacjonalne nie są jedynymi wartościami, jakie można odnosić do ludzkiego dobrostanu. Gdy zastanawiam się na przykład, czy dla mojej córki dobre jest to, że czyta powieści Prousta lub że chodzi na koncerty muzyki Telemanna czy Bernsteina, nie można zakładać w sposób niedorzeczny, iż w pełni potrafię zaspokoić swoją ciekawość, ustalając, jaką wartość samą w sobie ma czytanie tego rodzaju książek oraz słuchanie takiej muzyki, bądź też dowiadując się, czy pod wpływem tych czynności przypadły jej w udziale jakieś doznania lub czy doświadczyła ona stanów, które mogą być uważane 
za dobre dla niej niezależnie od tego, co sama miałaby do powiedzenia na ten temat. Zastanawiając się nad tym, mogę dojść do wniosku, że swoją ciekawość zaspokoję tylko wówczas, gdy dowiem się, jaką wartość mają dla niej te czynności z jej własnego punktu widzenia. Każdy, kto ma zdanie podobne do mojego, skłonny będzie zapewne uznać, że tego typu wartości powinny być względne wobec podmiotu, a to znaczy, że czytanie książek lub udział w koncercie muzycznym nie mogą być dla niej dobre dlatego, że są dobre bezwarunkowo, tj. bez względu na to, jakie doznania przypadałyby jej w udziale z tego powodu; nie powinien jednak zgodzić się z tezą, że są dla niej dobre tylko dlatego, iż wykonywanie tych czynności spowoduje, że będzie można przypisać jej jakąś własność, która znajduje się w katalogu jednej ze znanych teorii dobrostanu. Stanowisko to zakłada bowiem, że wartość rzeczy, których istnienie przebiega w granicach czyjegoś życia i które albo w ogóle nie dotyczą innych osób, albo jeśli mają na nie jakikolwiek wpływ, to dzieje się tak za ich dobrowolnym przyzwoleniem - a do takich rzeczy należy z pewnością czytanie książek, słuchanie muzyki oraz wiele innych powszechnie znanych zdarzeń i czynności - powinna zostać ustalana wyłącznie z punktu widzenia podmiotu, któremu się one przydarzają. Taką wartość nazywam wartościa osobowa (Rutkowski, 2015, s. 5-48).

Przyjęcie wewnętrznej perspektywy oceniania rzeczy mieszczących się w obrębie czyjegoś życia oznacza, że wyklucza się sytuację, w której coś może być dobre dla jakiejś osoby w ramach jej własnego dobrostanu również wtedy, gdy jest dla niej dobre z punktu widzenia ludzi, którzy w swojej ocenie kierują się wyłącznie własnym rozeznaniem na ten temat lub posiadają jakieś przypuszczenia o doznaniach, jakich ta osoba doświadcza pod wpływem rzeczy będącej jej przedmiotem. W ten sposób zakłada się, że wartości osobowe nie mogą być ustalane samodzielnie przez ludzi, których bezpośrednio nie dotyczą. To rodzi jednak mocny sprzeciw. Niektórzy uważają bowiem, że na podstawie dostępnej nam wiedzy o nas samych, każdy $\mathrm{z}$ nas potrafi $\mathrm{z}$ dużym wyczuciem wnioskować zarówno o wewnętrznych doznaniach innych osób, jak i o ich aksjologicznych postawach wobec rzeczy, które przyczyniają się do powstania u nich tego rodzaju doznań. Tego typu zastrzeżenie zazwyczaj nie spełnia pokładanych w nim nadziei, gdyż najlepsza nawet umiejętność rozumowania per analogiam nie może stanowić wystarczającego argumentu w tej sprawie. Jeśli bowiem przyjmuję, iż w ten sposób mogę sobie wyobrazić, jakie doznania przypadają w udziale innej osobie i jaką wartość może ona nadawać rzeczom, które przyczyniły się do 
powstania tych doznań, to powinienem mieć świadomość, iż jest to możliwe tylko dlatego, że wyobrażam sobie, jakie doznania i oceny przypadałyby w udziale mnie samemu, gdybym znalazł się w podobnej sytuacji lub zajął miejsce tej osoby. Nie dowiaduję się natomiast niczego o tym, co jest ważne i niezbędne dla ustalenia wartości osobowej, a mianowicie, czego faktycznie ta osoba doznaje, i jak to jest doświadczać przez nia pewnego rodzaju doznań z jej własnego punktu widzenia. Jeżeli patrzę na świat z perspektywy innej osoby i nadal pozostaję sobą, a w tym przypadku tak właśnie jest, to moje doznania i oceny nie muszą być - i najczęściej nie są - takie same, jak doznania i oceny tej osoby.

Wyjaśnienie oraz zrozumienie tego faktu nie powinno nastręczać zbyt wielu trudności. Ponieważ nasza wiedza o tym, jakie doznania przypadają w udziale innej osobie z powodu zachodzących w jej życiu zdarzeń, czy też o tym, jakie wartości przypisuje ona tym zdarzeniom pod wpływem tego, czego doznaje, wymaga wnioskowania, którego źródłem jest wyłącznie introspekcja, to nie wydaje się, aby można było sensownie zakładać, że wiedza ta będzie zawsze prawdziwa, a nawet - że będzie kiedykolwiek wystarczająca. Ów brak wiarygodności nie zależy bowiem w równym stopniu od wystąpienia każdego z obu czynników. Przypisywanie innym osobom określonych stanów umysłu z powodu zajścia pewnych okoliczności nie zawsze musi wiązać się z wewnętrzną perspektywą podmiotu, w tym sensie, że należałoby uznawać, iż prawdziwe twierdzenie na ten temat może wypowiedzieć tylko on sam. Wiarygodna wiedza na temat tego rodzaju faktów psychofizycznych możliwa jest niekiedy również z zewnętrznego punktu widzenia. Gdy wykręcamy komuś rękę, przytykamy do głowy pistolet, grożąc śmiercią, lub gdy poddajemy kogoś wymyślnym torturom, nietrudno odgadnąć, jakich uczuć w tego typu sytuacjach osoby te mogą doświadczać. To jednak nie oznacza, że w ten sposób jesteśmy zdolni do tego, aby pojąć znaczenie i wartość, jaką te doznania oraz wywołujące je zdarzenia bądź czynności mają dla nich samych z ich wewnętrznego punktu widzenia. Nawet prawidłowe przypisanie komuś stanów umysłu, jakie miałoby miejsce z obiektywnego punktu widzenia, mogłoby całkowicie pomijać lub niewłaściwie interpretować ich wpływ na ocenę, jaką ta osoba wyraziłaby de facto pod adresem rzeczy, które wywołały u niej tego rodzaju stany. Możemy czasami dziwić się, że ktoś nadaje inną wartość zdarzeniom, które w podobnych okolicznościach wywołują u niego takie same doznania jak u nas, niemniej nie powinniśmy upierać się, że w tej sytuacji możemy 
wiedzieć lepiej, co jest dla niego dobre, ani też, że możemy cokolwiek wiedzieć na temat tego, co jest dla niego lepsze, a co gorsze, jeśli nie potrafimy powiedzieć niczego sensownego o tym, jak to jest dla tej osoby doświadczać takich doznań.

Broniąc tego poglądu, nie zakładam, że wszystkie rzeczy, jakie komuś się przydarzają, są dla niego dobre lub złe wyłącznie z powodu stanu, w jakim się znajduje lub z powodu doznań, jakie przypadają mu w udziale. Nie twierdzę także, jakoby wszystko to, co uważamy za dobre lub złe dla jakiejś osoby, mogło być określane takim mianem wyłącznie przez tę osobę z jej własnego punktu widzenia. Czasem stan, w którym człowiek się znajduje, czy doznania, których doświadcza, są względnie nieistotne dla określenia, co jest dla niego dobre lub złe. Może zabrzmieć to paradoksalnie, ale w tym punkcie zgadzam się z tymi, którzy nie uznają wartości osobowych. Różnica między nami polega na tym, że choć twierdzę, iż taka sytuacja rzeczywiście może zachodzić, to jednak uważam, że dzieje się to sporadycznie, i do zaistnienia wymaga spełnienia ściśle określonych warunków, natomiast ci, którzy w tej sprawie mają przeciwne zdanie, utrzymują na ogół, że wartości odnoszone do konkretnych ludzi zawsze mają charakter bezosobowy lub relacjonalny, a wartości osobowe, tak jak ja je rozumiem, bądź w ogóle nie istnieją, bądź też przeświadczenie o ich istnieniu przeczy ustalonej w tej sprawie opinii, i jest niezgodne $z$ wiedzą o naturze ludzkiej.

Thomas Nagel, na przykład był przekonany, że takie zdarzenia, jak nagła i niespodziewana utrata czegoś nam drogiego, bycie wprowadzonym w błąd czy wyśmianym, nie dlatego powinny być uważane za złe dla osoby, której się przydarzają, że doświadcza ona określonych doznań, gdy się o nich dowiaduje, lecz z tego powodu, że źle jest po prostu ponosić szkody, być oszukanym czy wyszydzonym. „Naturalny pogląd jest taki - pisał - że odkrycie zdrady czyni nas nieszczęśliwymi dlatego, że źle jest być zdradzonym - nie zaś że zdrada jest zła, ponieważ jej odkrycie czyni nas nieszczęśliwymi” (Nagel, 1997, s. 15). Zaletą takiego rozumienia wartości byłoby niewątpliwie to, że każdy z nas mógłby je stosować do tego rodzaju przypadków bezpośrednio oraz że bylibyśmy w stanie wytłumaczyć w rozsądny sposób, dlaczego zajście tego typu okoliczności wywołuje u ludzi podobne doznania. Argument taki jest moim zdaniem rozsądny, gdy bierze się pod uwagę korzyści, jakie można by w ten sposób uzyskać, jednak nie jest to na pewno ten rodzaj argumentu, który mógłby uzasadniać słuszność środków, jakie należałoby przedsięwziąć, aby osiągnąć założony cel. Każdy 
zapewne rozumie, jak ważne jest, aby jednostkowa opinia i zasady ogólne nie odbiegały zanadto od siebie i że leży to w interesie zarówno pojedynczego obywatela, jak i całego społeczeństwa. Jeżeli wartości formułowane mają być na poziomie uniwersalnym i zaspokajać przede wszystkim wymogi dobra publicznego, to powstaje pytanie, jak znaleźć harmonię między prywatnym rozumieniem tych wartości przez poszczególne osoby a moralnym porządkiem, który jeśli ma dobrze spełniać swoją funkcję, musi zawierać mechanizm eliminujący konflikty powstające na styku tego, co partykularne, i tego, co powszechne. Ustalając, co jest dla jakiejś osoby dobre lub złe, i chcąc dokonać tego w taki sposób, aby w praktyce zapobiec moralnemu autokratyzmowi, nie możemy bezwiednie stosować się do zaleceń Nagela i brać pod uwagę tylko to, co z bezosobowego punktu widzenia powinno być dla tej osoby dobre lub złe, ale musimy też uwzględniać, co jest dla niej dobre lub złe w jej własnej perspektywie, a więc również i to, jakie konkretnie doznania są jej udziałem w tej sytuacji, jak to jest dla tej osoby doświadczać tego rodzaju doznań oraz co w tych okolicznościach ona rzeczywiście odczuwa lub co myśli na ten temat. Oznacza to, iż każda adekwatna teoria wartości, która rości sobie pretensje do wiarygodnego sądu na temat tego, co jest dobre dla konkretnych osób, musi zakładać warunek różnicujacy, a mianowicie musi głosić, że to, co jest dobre dla jednej osoby, może nie być dobre dla innej. Przy takim założeniu odkrycie zdrady nie może, wbrew temu, co sugerował Nagel, uczynić każdego człowieka nieszczęśliwym dlatego tylko, że źle jest być zdradzanym, gdyż wprowadzenie tego warunku powoduje radykalną zmianę zależności między doznaniami, jakie się nam przydarzają pod wpływem pewnych rzeczy, a wartością, jaką te rzeczy mają dla nas. W tej nowej sytuacji, nawet jeśli dla jednej osoby zdrada może być zła z tego powodu, że jej odkrycie spowodowało, iż osoba ta cierpi i jest nieszczęśliwa, to dla innej może być źródłem niemałego zadowolenia, a nawet szczęścia, że oto nadarzyła się okazja, stanowiąca jednocześnie dobry pretekst, aby uwolnić się od niechcianego związku z innym człowiekiem bez narażania się na moralną krytykę.

Odwołanie się do warunku różnicującego stanowi mocny argument na rzecz wartości względnych wobec podmiotu i z tego powodu poważnie utrudnia, a niektórzy mogliby nawet powiedzieć, że wręcz uniemożliwia, definiowanie dobrostanu w kategoriach rzeczy, w odniesieniu do których powiedzenie, że są dobre lub złe dla konkretnej osoby oznacza, iż wartość tych rzeczy zależy tylko od ich natury i jest neutralna wobec przysługujących 
tej osobie własności. Nie musi jednak prowadzić do wniosku, że coś może być dobre lub złe dla niej wyłącznie wtedy, jeśli jest takie z jej własnego punktu widzenia, tj. dlatego, że ona tak uważa; najczęściej przemawia za słusznością jakiejś obiektywnej wersji względności wobec podmiotu, która w konsekwencji konstytuuje wartości, nazywane przeze mnie relacjonalnymi. Taki sposób rozumowania jest dzisiaj dość rozpowszechniony. Connie Rosati, na przykład, uważa, że bezwzględnie każda interpretacja wyrażenia „dobre dla kogoś” powinna obejmować warunek różnicujący i że tylko te rzeczy mogą być uznane - z wewnętrznego i pozamoralnego punktu widzenia - za dobre dla jakiejś osoby, o których da się wiarygodnie powiedzieć, że jej odpowiadaja. Takie postawienie sprawy rodzi jednak wiele wątpliwości. Czy to oznacza, że powinniśmy zakładać, iż branie narkotyków lub zabijanie ludzi mogłoby być dobre dla pewnych osób, jeśli uważałyby one, że odpowiada im wykonywanie tych czynności? Czy jeśli używamy pojęcia dobrostanu w taki sposób, że odnosi się ono do tego, co sprawia, że życie jakiejś osoby jest dobre lub złe dla niej samej, to czy moglibyśmy powiedzieć, że życie osoby, której odpowiada branie narkotyków lub zabijanie innych ludzi jest dla niej lepsze wtedy, gdy to robi, niż byłoby wówczas, gdyby tego nie robiła? Gdybyśmy przyjęli, iż istniejąca między tymi osobami a wykonywanymi przez nie czynnościami relacja odpowiedniości, od której zależeć ma ostatecznie, czy te czynności są dobre dla tych osób, ustalana jest przez nich z ich własnego punktu widzenia, to odpowiedź na oba pytania musiałaby być pozytywna. Rosati nie zakłada takiej ewentualności (Rosati, 2006, s. 110, 121-122). Odpowiedniość, na której zasadza się sąd, że coś jest dobre dla kogoś, nie jest według niej tożsama z żadnym subiektywnym stanem ani doznaniem. Rzeczy mogą nam odpowiadać na wiele różnych sposobów. To, czy coś jest odpowiednie dla kogoś w tym znaczeniu odpowiedniości, o którą tu chodzi, zależy według niej głównie od czynników, które charakteryzują tego człowieka również z zewnętrznego punktu widzenia. Należą do nich między innymi jego cechy fizyczne, osobowość, posiadane zdolności czy kultura. Oznacza to, iż zażywanie narkotyków może być dla pewnej osoby rzeczą nieodpowiednią, nawet jeśli doświadczałaby ona doznań, które utwierdziłyby ją w przekonaniu, że jest wprost przeciwnie. $\mathrm{Z}$ tego samego powodu dochodzimy też do wniosku, że zabijanie ludzi nie może sprawić, iż dobre będzie życie osoby trudniącej się tym procederem. Gdyby nawet jakimś trafem zdarzyło się tak, że tego typu czynności byłyby odpowiednie dla jakiejś osoby również z zewnętrznego punktu widzenia, który bierze pod 
uwagę, jak pamiętamy, wyłącznie obiektywnie ustalone własności tej osoby, to w odwodzie zawsze pozostaje jeszcze pytanie, co jest dla niej lepsze, a co gorsze. Tak więc jeśli zażywanie pewnych narkotyków lub zabijanie ludzi byłoby dobre dla jakiejś osoby, lecz miałoby takie skutki, że uniemożliwiałoby jej na przykład osiąganie innych dóbr lub obniżyłoby poważnie jakość jej życia, to moglibyśmy nie tylko powiedzieć, że w tych okolicznościach istnieje racja przemawiająca za tym, aby osoba ta nie postępowała $\mathrm{w}$ taki sposób, ale również, że ona sama ma rację, aby tego nie robić.

Sprzeciw wobec wszelkich prób wyjaśniania tego, czym jest dobro lub zło dla jakiejś osoby w kategoriach jej subiektywnych doznań oraz podejmowanych przez nią na tej podstawie ocen, wynika niekiedy z przekonania, że tego rodzaju wartości implikowane są przez bezosobowe racje wynikające bezpośrednio z wewnętrznych własności rzeczy, które powodują, że są one dla kogoś dobre lub złe również z ich własnego punktu widzenia. Pogląd ten zakłada, iż powiedzenie, że coś jest dobre dla jakiejś osoby, oznacza nie tylko, że ta osoba ma racje, aby tak myśleć, ale również, że tak samo mogą myśleć inni ludzie. Parfit skłonny jest uważać, że podobnie rzecz się przedstawia, gdy w taki sposób oceniamy całość czyjegoś życia: jeśli stwierdzamy, że pewne życie jest dobre dla jakiejś osoby, to mamy na myśli zarówno to, że ma ona racje za tym, aby nim żyć, jak i to, że inni ludzie także mają racje za tym, aby ta osoba żyła tym życiem (Parfit, 2011, s. 101-107). Ponieważ racje te są neutralne wobec podmiotu oceniającego w tym sensie, że nie zależą w jakimkolwiek stopniu od charakteryzujących go własności, to można przypuszczać, że z tymi samymi racjami mamy do czynienia również wtedy, gdy wartość rzeczy oceniana jest z punktu widzenia osoby, do której ją odnosimy, jak i wtedy, gdy oceniają ją osoby postronne. To jest jednak sprzeczne z tym, co głosi warunek różnicujący, a więc, że jeśli jakaś rzecz jest dobra dla jednej osoby, nie musi to oznaczać, że nie może nie być też dobra dla innej. Warunek różnicujący nie powinien obowiązywać, jeżeli rzecz, którą oceniamy z punktu widzenia jakiejś osoby - bez względu czy będzie to jednorazowy akt, zdarzenie, czy całe jej życie - oddziałuje na kogoś bezpośrednio lub pośrednio bądź, jak przypuszczamy, jej zajście będzie miało w przyszłości wymierne konsekwencje dla innych ludzi lub zwierząt, a szczególnie jeżeli te konsekwencje będą dla tych istot negatywne i nie będzie na nie z ich strony zgody, natomiast tam gdzie zajście takiej rzeczy dotyczy wyłącznie podmiotu, ze względu na którego przypisujemy jej taką, a nie inną wartość, i w żaden sposób nie wpływa na jakość doznań 
ani życia kogokolwiek innego, lub tam, gdzie ktoś na taki wpływ wyraził dobrowolne przyzwolenie, brak tego warunku jest jawnym naruszeniem autonomii jednostki oraz przysługujących każdemu człowiekowi swobód i wolności do postępowania wedle własnych przekonań i prowadzić może do jakiejś odmiany despotyzmu moralnego lub represji ze strony społeczeństwa, uzasadnionych jedynie brakiem czyjejś zgody z panującą opinią na temat jego spraw osobistych.

Nie bez znaczenia jest również i to, że obiektywny charakter racjonalności, który ma zakładać rozumienie, czym jest dobro oraz zło dla jakiejś osoby w kategoriach neutralnej wobec podmiotu koncepcji wartości, nie jest $\mathrm{w}$ tej kwestii argumentem w pełni rozstrzygającym. Ci, którzy wspierają idee wartości bezosobowych bądź relacjonalnych, i sądzą, że najlepiej wyjaśniają one, które rzeczy są dobre, a które złe dla jakiejś osoby, zakładają zwykle, że wykonanie pewnych działań byłoby dla tej osoby dobre wówczas, gdyby miała ona rację, aby w ten sposób postąpić, i gdyby racja ta wynikała $\mathrm{z}$ decyzji, jaką $\mathrm{w}$ tej sprawie podjęła na podstawie racjonalnego namysłu - który za Rawlsem zwykło nazywać się rozważną refleksja (Rawls, 1994, s. 559), tj. będąc w pełni świadoma wszystkich istotnych dla tej kwestii faktów i po dokładnym rozważeniu najważniejszych konsekwencji. Z takiego nastawienia wynikają bezpośrednio dwa wnioski: (1) że gdyby, zgodnie z przyjętym założeniem, ktoś powiedział, iż z jego własnego punktu widzenia dobre jest dla niego wykonanie jakiegoś czynu, to twierdziłby tym samym, iż postępowanie to ma dla niego taką, a nie inną wartość, dlatego że decyzję o wykonaniu tego czynu podjął na podstawie racji pochodzących ze starannie i dogłębnie przeprowadzonego rozumowania, a także (2), że gdybyśmy chcieli powiedzieć, iż wykonanie jakiegoś czynu jest dobre dla konkretnej osoby, musielibyśmy stwierdzić, iż postępowanie to z zewnętrznego punktu widzenia ma dla niej taką, a nie inną wartość, dlatego że decyzja o wykonaniu tego czynu może zostać podjęta przez każdego z nas na podstawie racji pochodzących z takiego właśnie namysłu. Nie wydaje się, aby powstanie tego typu sądów było tak proste zarówno w jednym, jak i drugim przypadku. Najlepsze nawet zasady podejmowania racjonalnych decyzji nie zawsze prawidłowo stanowią o tym, co jest dla nas faktycznie dobre, a co złe. Interpretacja wyrażenia „coś jest dobre dla kogoś” w kategoriach obiektywnych racji zakłada, że czyjeś postępowanie można dezaprobować lub krytykować, dlatego że narusza przyjęte zasady racjonalnego wyboru bądź dlatego że nikt, włącznie ze sprawcą, nie postąpiłby w ten 
sposób, gdyby prawidłowo ocenił skutki, jakie ono powoduje, w żadnym zaś razie nie prowadzi do wniosku, że można tak czynić wyłącznie z tego powodu, że jest ono złe dla osoby, która w ten sposób postępuje. Dlaczego tak się dzieje? Powód jest stosunkowo prosty - nawet jeśli zakłada się, że w tego rodzaju racjonalnym namyśle nie popełniono błędów odnośnie do faktów i spowodowanych przez nie konsekwencji, to nie wynika z tego, że otrzymane na tej podstawie racje wyznaczają w sposób ścisły treść sądów wartościujących na temat danej osoby; one mogą je co najwyżej luźno ukierunkowywać, lecz w ostateczności wartość, jaką dla pewnych osób stanowią te konkretne zdarzenia bądź czynności, które nie dotyczą innych ludzi wbrew ich woli, można ustalić tylko z punktu widzenia tych osób i na podstawie tego, czym jest dla nich to, że mają one miejsce właśnie w ich życiu. Stoję na stanowisku, że neutralne wobec podmiotu racje nie generują w tych okolicznościach ocen na temat tego, co jest dla nas dobre, a co złe, ani też na temat tego, co jest dla nas lepsze, a co gorsze. Tego typu decyzja ma zawsze charakter psychologiczny i przez to jest $\mathrm{w}$ jakiejś mierze arbitralna. Zdaję sobie sprawę, że tak kategoryczne twierdzenie może wywołać odczucia niedowierzania, a nawet sprzeciwu, sądzę jednak, że w odniesieniu do wartości osobowych jest rzeczą niemożliwą, aby takie kwestie, jak podejmowanie decyzji aksjologicznych czy formułowanie na tej podstawie sądów o dobru i złu, ucieleśniały czysto racjonalny punkt widzenia, który zawiera $\mathrm{w}$ sobie idee bezstronności lub bezosobowości. Wyciągam z tego wniosek, że fakt, iż ktoś spełnia wszystkie zasady rozważnej refleksji i jest idealnie racjonalny, nie pomoże nam wyrokować o tym, jakie wartości ostatecznie przypisze on rzeczom, które mogą sprawić, że jego życie będzie dobre lub złe dla niego samego. Niezrozumienie tego prowadzi niekiedy do zdziwienia, że inteligentna, wykształcona i mądra osoba dochodzi po namyśle do wniosku, że najlepszą dla niej rzeczą jest liczenie źdźbeł trawy na skwerach parkowych lub poszukiwanie metody komunikowania się z asparagusami, jednak stan zaskoczenia wywołany czymś, co uważa się za nieoczekiwane lub niezwykłe dla nas samych, nie jest w żadnym razie dobrym przykładem argumentum ad rem, który należałoby brać pod uwagę w prowadzonej dyskusji.

Nie rozstrzygam tutaj, które wartości rzeczywiście istnieją, a które są tylko wytworem filozoficznej wyobraźni. Nie zakładam też, że na dobrostan konkretnej osoby składają się tylko wartości osobowe. Jeżeli uznamy, że twierdzenie o istnieniu innych wartości jest wiarygodne, to uważam, że 
to, co sprawia, iż życie jest dobre lub złe dla jakiejś osoby, może być oceniane w kategoriach wartości bezosobowych, jak i w kategoriach wartości względnych wobec podmiotu, które ustala się - tak jak chcą tego na przykład zwolennicy listy obiektywnej - z zewnętrznego punktu widzenia. Dzieje się tak na przykład wówczas, gdy jakość życia tej osoby zależy od rzeczy, które jednocześnie wpływają na jakość życia innych ludzi. Kiedy jednak mówimy, że coś jest dobre lub złe dla konkretnej osoby, i mówiąc to, mamy na myśli rzeczy, które w żaden sposób nie dotyczą interesów innych ludzi - gdyż mieszczą się, łącznie ze skutkami, jakie powodują, w granicach życia tej osoby - lub te, które dotyczą innych wyłącznie za ich przyzwoleniem - to wydaje się, że ocena ta jest prawidłowa tylko wtedy, jeśli jest zgodna $\mathrm{z}$ wartością, jaką osoba ta nadaje tym rzeczom niejako od wewnątrz, tj. z jej własnego punktu widzenia.

Teza ta ma praktyczne zastosowanie, gdy porównujemy ze sobą wartość istnienia i nieistnienia. Prawidłowa odpowiedź na pytanie, czy istnienie może być lepsze albo gorsze od nieistnienia, ma doniosłe znaczenie z teoretycznego punktu widzenia - gdzie najbardziej liczy się ustalenie prawdy bądź znalezienie najlepszych argumentów, a w dalszej kolejności również sformułowanie na tej podstawie najlepiej uzasadnionego rozwiązania problemu, który leży u podstaw tego niewinnego, zdawałoby się, pytania - oraz ze względu na rolę, jaką może mieć na przykład dla osób nieuleczalnie chorych lub w jakiś inny sposób dotkniętych przez los, a także dla tych, którzy zdając sobie sprawę z odpowiedzialności za jakość życia przyszłych ludzi, stoją przed decyzją o powołaniu ich do istnienia. Tak naprawdę może być ona w większym lub mniejszym stopniu ważna dla każdego z nas bez względu na to, w jakiej znajdujemy się sytuacji. Jeżeli okazałoby się na przykład, że w porównaniu z przeżywanym właśnie przez jakąś osobę życiem, które nie jest obarczone cierpieniem przekraczającym standardy, jakim w tej mierze podlegają pozostali ludzie, lepiej dla niej byłoby jednak, gdyby nigdy nie istniała, to wielce prawdopodobne jest, że świadomość tego faktu mogłaby wywołać u niej głęboki resentyment w stosunku do osób, których działania stanowiły konieczną część przyczyny jej zaistnienia, a nawet spowodować podjęcie kroków zmierzających do samounicestwienia.

Sprawy te są ważne nie tylko w obrębie pojedynczego życia, mają one także doniosłe znaczenie dla relacji międzyludzkich, które decydują o poziomie dobrostanu w grupach społecznych oraz o odpowiedzialności za wykonywane czynności wobec innych ludzi. To między innymi powoduje, 
że wielu z nas chce wiedzieć, jak powinniśmy oceniać wzajemną wartość istnienia i nieistnienia i kto może tego dokonać. Gdy uznamy, że możliwe jest, aby życie każdego z nas mogło być oceniane w dużo szerszej perspektywie aniżeli ta, którą wyznaczają wartości osobowe, niektórzy dojdą do przekonania, iż cała dyskusja nie musi mieć internalistycznego charakteru, a to oznaczałoby, że prędzej czy później dojdą oni prawdopodobnie również do przekonania, że nie trzeba zakładać, iż w tej kwestii mamy mówić wyłącznie o subiektywnych decyzjach podmiotu. W tej perspektywie wartość, jaką życie ma dla osoby, która nim żyje, musiałaby uwzględniać również stanowisko, jakie w tej sprawie mają inni ludzie i w ten sposób zostać niejako dookreślona z zewnątrz - poprzez odwołanie się do obiektywnych wartości rzeczy (są nimi wartości bezosobowe oraz wartości względne, ustalane z zewnętrznego punktu widzenia na podstawie - całkowicie niezależnego od podmiotu - przekonania o posiadanych przez ten podmiot własnościach oraz na podstawie takiegoż samego przekonania o tym, jaką mają one dla niego wartość), które przyczyniają się do tego, że życie tej osoby jest dobre lub złe dla niej samej. Gdyby tak było, to wartość życia nie byłaby ani pojedynczą wartością osobową, ani też jednolitą całością, na którą składają się wyłącznie wartości osobowe, lecz stanowiłaby swoisty konglomerat, w którym poszczególne wartości osobowe istniałyby w jakiejś określonej relacji do pozostałych wartości obiektywnych, a ich wpływ na ostateczną ocenę czyjegoś życia (tak samo zresztą, jak i wpływ wartości obiektywnych) pozostałby na zawsze nieznany.

Nie wydaje się jednak, aby można było w ten sposób ustalić wartość życia dla przeżywającej go istoty w takim sensie wartości tego życia dla tej osoby, o jaki chodzi w tego rodzaju ocenie. To, co zakłada eksternalistyczny punkt widzenia, sprowadza się do kilku porządkujących czynności: sporządzenia numerycznego katalogu rzeczy, które wpływają na to, że życie jakiejś osoby może być dla niej lepsze lub gorsze, określenia ich jednostkowej wartości i - po starannym przeprowadzeniu inwentaryzacji wszystkich w ten sposób opisanych składników - do wykonania odpowiednich działań arytmetycznych mających na celu ustalenie końcowego bilansu dobra i zła. Wartość, jaką ma dla nas nasze życie, w ostatecznym rozliczeniu nigdy nie jest jednak funkcją czynności, które można przeprowadzić niezależnie od tego, co sami ten temat sądzimy. Podstawowy błąd, jaki popełniały wszystkie uznane teorie dobrostanu, polegał na tym, że zbyt dużo miejsca poświęcano w nich kwestii, czym jest to, co sprawia, że życie jakiejś osoby jest dobre lub 
złe dla niej samej, a prawie w ogóle nie zajmowano się tym, co wydaje się w tej sprawie najważniejsze, a mianowicie, kto ma decydować o tym, czym jest to coś, a także o tym, jaki wywiera ono wpływ na ocenę jego istnienia. Wydaje się zatem, i trzeba to mocno podkreślić, że wartość, jaką ma dla kogoś jego własne życie, nie może wynikać wyłącznie z kalkulacji, której poddawane są rzeczy wyposażone w wartości obiektywne i która sprowadza się zasadniczo do prostego zabiegu buchalteryjnego: dodawania oraz odejmowania przynależnego im dobra i zła. Jeśli nie wprowadzimy żadnych ograniczeń odnośnie do tego, z jakiej perspektywy należy dokonywać ocen, których przedmiotem jest czyjejś istnienie bądź nieistnienie, to ciągle będzie nam się wydawać, że proste zestawienie ze sobą zdarzeń mających miejsce w życiu jakiejś osoby lub własności, które można jej przypisać w jednym lub drugim stanie, musi ostatecznie wyznaczać porównawczą wartość, jaką oba stany mają dla niej, niezależnie od tego, jak ona sama ocenia własne życie lub swoje nieistnienie. Aby wpływać na ostateczną wartość, jaką życie ma dla osoby, która nim żyje, i tym samym na jakość jej dobrostanu, te zdarzenia i własności muszą nie tylko odnosić się do tej osoby lub jej przynależeć, ale - co ważniejsze - musi ona faktycznie doświadczyć tego, jakby to było, gdyby się jej przydarzyły. Kiedy ktoś nie istnieje, nie ma jednak niczego, co zgodnie z przedstawionym tu poglądem powodowałoby, że mówienie o jego dobrostanie ma jakikolwiek sens.

\section{Bibliografia}

Brock, D.W. (1988). Paternalism and Autonomy. Ethics, 98, 550-565.

Brudney, D. (2009). Beyond Autonomy and Best Interests. Hastings Center Report, $39,2,31-37$.

Dworkin, R.M. (1993). Life's Dominion: An Argument About Abortion, Euthanasia, and Individual Freedom. New York.

Glover, J. (1977). Causing Death and Saving Lives. London.

Groll, D. (2011). What Health Care Providers Know. Hastings Center Report, 41 (5), 27-36.

Groll, D. [w druku]. Medicine and Well-Being. W: G. Fletcher (ed.), The Routledge Handbook on Well-Being. New York: Routledge.

Hurka, T. (1987). „Good” and „Good For”. Mind, 387, 71-72. 
Moore, G.E. (2003). Zasady etyki. Warszawa: De Agostini Polska.

Nagel, T. (1977). Pytania ostateczne. Warszawa: Fundacja Aletheia.

Nagel, T. (1997). Widok znikad. Warszawa: Fundacja Aletheia.

Parfit, D. (2012). Racje i osoby. Warszawa: Wydawnictwo Naukowe PWN.

Parfit, D. (2011). On What Matters. T. I. Oxford-New York: Oxford University Press.

Railton, P. (1986). Moral Realism. Philosophical Review, 95, 2, 163-207.

Rawls, J. (1994). Teoria sprawiedliwości. Warszawa: Wydawnictwo Naukowe PWN.

Regan, D.H. (2004). Why Am I My Brother's Keeper?, W: R.J. Wallace, P. Pettit, S. Scheffler, M. Smith (eds.), Reason and Value: Themes from the Moral Philosophy of Joseph Raz (s. 202-230). Oxford: Clarendon Press.

Rosati, C.S. (2006). Personal Good. W: T. Horgan, M. Timmons (eds.), Metaethics After Moore (s. 107-132). Oxford: Oxford University Press.

Rutkowski, M. (2015). Wartość osobowa. Analiza i Egzystencja, 32.

Saja, K. (2015). Etyka normatywna. Między konsekwencjalizmem a deontologia. Kraków: Universitas.

Smith, M. (2003). Neutral and Relative Value after Moore. Ethics, 113, 576-598.

Sumner, L.W. (2003). Welfare, Happiness, and Ethics. New York.

Veatch, R. (2009). Patient Heal Thyself. Oxford-New York: Oxford University Press.

\section{CAN EXISTENCE BE BETTER OR WORSE THAN NONEXISTENCE? PART I}

\section{Summary}

The aim of this paper is to examine whether there is any possibility to compare the value of someone's existence with his nonexistence. The final conclusion is that such a comparative evaluation can never be made in a meaningful and valid manner. Nobody can know as well whether he would be better off or worse off created than he would have been had he never existed. 